\title{
A Processual Approach to the Study of Transitions of Middle School (Gymnasium) Teachers
}

\begin{abstract}
SUMMARY
This paper presents the results of research carried out during the first stage of the Polish education system transition process initiated by the education reform of 2017. The study was conducted with teachers of schools to be dissolved, who decided to transform their institutions into a new type of school - general education secondary school (lyceum), while retaining staff and organizational resources of the hitherto middle schools (gymnasium). A processual approach adopted in this project allowed me to capture the changes as they were happening and the analysis of the conditions of transition trajectories.
\end{abstract}

\section{Keywords:}

middle schools teachers, transitions, managing transitions strategy, processual approach

\section{INTRODUCTION}

The term 'transition' is applied in social sciences to describe various changes experienced by people in their lifetime. It indicates a transition from one state (or condition) to another: from school to work (Müller \& Gangl, 2003; Piróg, 2013), from a lower to a higher professional position (Sullivan \& Al Ariss, 2019), from employment to retirement (Moffatt \& Heaven, 2017), from one place of residence to another (McLeod, Heriot, \& Hunt, 2008). It also describes changes involving social roles, e.g. becoming a wife (Brotherson \& Moen, 2011; Taubman-Ben-Ari et al., 2009),

1 Faculty of Social Sciences, University of Warmia and Mazury in Olsztyn, Poland. E-MAIL: h.a.kedzierska@uwm.edu.pl oRCiD: https://orcid.org/0000-0003-4187-2764 
and the social status of individuals (Manstead, 2018). Transitions are an inseparable part of human life and also concern organizations established by individuals.

The precedent of the dissolution of middle schools (gymnasiums) in Poland, initiated with the education reform of 2017, has triggered transition processes (both organizational and individual) on a massive scale not experienced before ${ }^{2}$. These processes affected thousands of teachers employed in over six thousand middle schools. Eschewing assessments of decisions made by central authorities, it can still be concluded that the closing down of schools has resulted in significant 'disturbances' in the professional lives of teachers and in educational organizations created by them. Simultaneously, for educational researchers such a rapid and systemic change spread over time has 'opened' fields of analysis of these reformatory processes that are difficult or actually impossible to explore empirically under evolutionary circumstances.

In social sciences, transition studies are conducted within the framework of two basic strategies, i.e., static and dynamic. As stressed by T. Zittoun (2009), the static approach facilitates the identification and description of differences between two phases: A (the beginning) and B (the end) of transition. The term 'transition' then designates the fact that B replaces A. This approach, although allowing researchers to describe differences between the endpoints: the initial and the final, does not explain the mechanisms of the change itself, in other words: how A becomes $\mathrm{B}$. In the case of the transition process triggered by the dissolution of middle schools, the static approach makes it possible to collect a number of interesting data concerning, for instance, changes in the employment structure and adaptive problems experienced by former middle school teachers who undertake work in schools of other types. However, the analysis of the transition process itself - its multidimensional and complex trajectory, dynamics, as well as individual and organizational determinants - is not possible.

2 Education reform of 2017 transformed the school structure, reintroducing the education system that had been in operation prior to 1999. The following types of schools were dissolved: 6-year primary school, 3-year middle school (gymnasium), and level 2 schools: 3-year general education secondary school (lyceum), 4-year secondary technical school, as well as 3-year basic vocational education school. The present school structure is as follows: 8-year primary school; secondary level schools, i.e., 4-year general education secondary school; 5-year secondary technical school; 3-year $1^{\text {st }}$ degree vocational education school; 2-year $2^{\text {nd }}$ degree vocational education school; 3-year special vocational training school; post-general education secondary school. These changes influenced fundamental issues for the education process, such as: core curriculum, organization of the teaching process, including the number of teaching hours, facilities, staff and management. For more extensive information concerning the outcomes of the reform, see: Changes in the Education System: The Supreme Chamber of Control Report (2019). 
This paper presents the results of research carried out during the first stage of the Polish education system transition process initiated by the education reform of 2017. The study was conducted with teachers of schools to be dissolved, who decided to transform their institutions into a new type of school - general education secondary school (lyceum), while retaining staff and organizational resources of the hitherto middle schools (gymnasium). A processual approach adopted in this project allowed me to capture the changes as they were happening and the analysis of the conditions of transition trajectories.

\section{THEORETICAL FRAMEWORK}

Pursuant to the decision of educational authorities, the employees of middle schools to be dissolved could undertake work, in accordance with possessed qualifications, either in 8-grade primary schools or in secondary schools of various types. The implementation of this transition pattern was associated with the dispersion of a given middle school teaching staff and teachers' employment in new organizational environments.

A different transition path was followed by those schools whose teachers undertook the effort to transform the entire school organization (middle school) into a new type, while preserving the existing human and organizational resources. This solution is of particular epistemic interest since transition in this case consists of two concurrent and closely linked processes: teachers' professional transitions and organizational transition.

Due to the complexity of the subject of research (individual and organizational dimensions) and scarce educational research concerning transition available (Kędzierska, 2019), the theoretical framework of the project at the stage of conceptualization was designed based on dynamic theories in the fields of: Managing Transitions (Bridges), psychological concepts of transitions in life course theory (Zittoun), Transitions and Learning Through the Lifecourse (Ecclestone), and Transition in Career Counselling developed by Nancy M. Schlossberg. These theories facilitated focusing on the dynamic dimension of transitions rather than the static one. Transitions do not merely involve a situational movement, a transfer within an organization or within its segment, but are most of all "a psychological process consisting of three stages that individuals go through when assimilating the changes and adapting themselves to new situations caused by these changes” (Bridges, 2008, p. 3). Transition trajectories tend to be non linear and do not necessarily feature an upward attribution, but are characterized by many tensions, ruptures and turning 
points (Zittoun, 2009), and changes of direction that force individuals to redefine their manner of thinking and acting. Transitions always occur in some context. Consequently, in order to understand the process, the analysis of the circumstances in which an event occurred (or, despite such plans, did not) is necessary as well as examining the significance of this situation for the individual and the person's environment (Schlossberg, 1981). Effective transitions require a better understanding of how people progress cognitively, emotionally and socially between changes, allowing them to move between different subjects and "effectively navigate the complex demands of different contexts” (Ecclestone, 2009, p. 12).

The theoretical perspective adopted at the stage of research planning led to formulating the fundamental research question: How does a transition process occur in middle schools being transformed into general education secondary schools in the individual (professional) and organizational dimensions? The question was formulated as a preliminary identification of the subject of study and was operationalized during its course. This initial conceptualization allowed, however, for determining the limits of the studied case while remaining sensitive to "a new knowledge emerging from the study" (Flick, 2010, p. 93).

The manner of formulating the research problem implied the application of a processual strategy that made it possible, as A.M. Pettigrew described it metaphorically (1997), "to catch this reality in flight” (1997, p. 347), in its temporal dimension, including the past, the present and the future, recording the behaviour of people within the determined time sequences and between them.

\section{A PROCESSUAL RESEARCH APPROACH: SPECIFICITY AND PROCEDURES}

A processual approach is applied in many disciplines of social sciences. In dynamic psychological theories of human development (Rzechowska, 2011; Fogel, 2006), it focuses on discovering the essence of transformations that a given phenomenon is subject to in a specific context and time frame. Studies aim at identifying (and designing a hypothetical model) the process that shapes a given phenomenon, i.e., determining what forms it assumes and which paths its transformation follows. When studying the course and mechanisms of developmental processes, a researcher rarely possesses sufficient knowledge concerning the studied phenomenon, hence the conceptual framework of the project is designed on the basis of the existing theoretical concepts. These allow for the initial conceptualization of the subject of study and provide the researcher with conceptual categories to identify the course of the phenomenon and its mechanisms. The methods of collecting 
empirical data depend on the aims of the study (video recordings, interviews, preexisting data analysis), and the empirical data obtained serve as the basis for the reconstruction of the individual course path. Irrespective of the source of rich empirical data, a processual analysis involves a few characteristic phases/stages at each of the two levels of analysis: individual cases and a set of individual cases, whereas at each subsequent stage of data processing, the analyzed cases retain their initial properties (Rzechowska, 2011).

In sociological studies of organizations, a process is defined as a "sequence of individual and collective events, actions, and activities unfolding over time in context" (Pettigrew, 1997). It should not be perceived, however, as the main stream of a river, but rather as a "a river basin where there may be several streams all flowing into one another, dependent on one another for their life force and shaping and being shaped by varieties of terrain, each constraining and enabling in different intensities and ways" (Pettigrew, 1997, p. 340). Hence, processual studies of organizational change do not aim at creating a case history (a chronological description of events), but a case study in which course patterns are searched for and mechanism shaping all patterns in the observed processes are identified and described. Generally, "a process has to be conceptualised as a story. It then becomes necessary to unravel it in order to make its progression intelligible” (Bidart, Longo, \& Mendez, 2013, p. 745).

The analytical framework for a processual analysis understood in this way consists of four fundamental dimensions: contexts and ingredients, sequences, driving forces, and significant turning points.

Each process occurs in the context consisting of many elements. Concurrently, the process itself affects the context, generating new elements that help to change it. The relationship between the process and the context involves a reciprocal mutual construction. Any action cannot be interpreted without referring to the context, and the context cannot be described without referring it to this action because one facilitates the understanding of the other. The complexity of context and its variability may cause many analytical problems. However, as C. Bidart, M.E. Longo, and A. Mendez (2013) explain, each element of the context is not of significance at each phase of the change. In reality, context analysis of a process involves the identification of elements that are of key importance for its course. Consequently, a process may contain elements that are initially insignificant, but they become so along with the dynamics of the transition development. Dividing the process into sequences makes it possible to examine significant elements and to include in the analysis those elements of the context that facilitate the identification of mechanisms, driving forces and a variability course. 
The process of transition consists of different sequences, each characterized by a (relatively stable) configuration of ingredients. Whenever the configuration of ingredients changes, a new sequence begins. Any process consists of many cycles which result from interactions among many ingredients that influence each other, thus modifying their own meaning and the meaning of the process itself. A transition to subsequent sequences may follow from a rapid change caused by unforeseen external events or from a slower change - an effect of an accumulation of a combination of ingredients gradually changing into a new configuration. In processual analysis, such specific events that cause crises, the emergence of an alternative and changes in orientation are termed 'turning points'. These have a few characteristic features. Turning points are not continuous and gradual changes, but rather complex transformations that appear within a short time in relation to the analyzed process. Their occurrence is unpredictable and they are perceived as sudden and unexpected. A 'normal' course of events should evolve differently. The main criteria of determining turning points include: intensity, pace and range of changes, along with their unpredictability and irreversibility. A turning point additionally implies the notion of an intersection - a choice that must be made between at least two different paths.

The notion of a driving force refers to the "principle generating the movement of the ingredients and of their configurations over time” (Bidart, Longo, \& Mendez, 2013, p. 6.). Driving forces may be of different types. They may result from the change itself, its program, rhythm and evolution, or from the manner in which people who are involved in the change relate to it: whether they accept or reject it. The energy that generates subsequent sequences of transition may also result from tensions that appear between different ingredients of the change. In this case, the process dynamics follows from the interaction of opposing forces. An evident aim that governs decisions and actions may also serve as a driving force. The wish to achieve this aim generates movement that is correlative to a number of decisions and activities which modify the ingredients and their configurations. A new alternative then emerges and it leads to the period of intense reflection.

Four conceptual pillars, briefly characterized here, that form the core of the processual research approach, are separated from each other during the analysis in order to be integrated in the course of interpretation. Together they form the framework of the process analysis and their analytical combination constitutes their 'added value'. 


\section{METHODOLOGY}

The study of transitions of middle school teachers was conducted as a theory-led case study (Simons, 2009). The research project, in concord with the presented theoretical framework, was divided into two stages. The first stage focused on the identification of the transition between the first (endings) and the second (neutral zone) phase of transition, when changes within the organization initiate a psychological process of the reconstruction of old manners of action and identities of the employees, triggering "critical internal changes and psychological reorientations" (Bridges, 2008, p. 5). The second stage, planned to begin in June 2020, will aim to analyze the process of constructing the "temporary I" and transition trajectories between the second and third phases of transition (neutral zone and the phase of new beginnings).

The first stage of the study was conducted in five schools located in Polish cities. These schools were transformed from middle schools (gymnasium) to general education secondary schools (lyceum), and during the conducted research their organizational structure contained both middle school and secondary school classes due to the enrolment scheme consistent with the new reform. Empirical data were collected via focused interviews (Barbour, 2011) with teachers, who had been informed about the aim of the study and consented to participate in it. In total, 62 teachers were interviewed (5 focus groups) from two large cities. The study was conducted from March to June 2019. The interviews, with teachers' consent, were recorded with a recording device, then transcribed and finally processually analyzed in accordance with the cycle suggested by A.M. Pettigrew, involving the following stages of analysis: "the core question of the study $\rightarrow$ related themes and questions $\rightarrow$ preliminary data collection $\rightarrow$ early pattern recognition $\rightarrow$ early writing $\rightarrow$ disconfirmation and verification $\rightarrow$ elaborated themes and questions $\rightarrow$ further data collection $\rightarrow$ additional pattern recognition across more case examples $\rightarrow$ comparative analysis $\rightarrow$ a more refined study vocabulary and research questions” (1997, p. 344).

\section{THE PROCESS OF TRANSITION OF MIDDLE SCHOOL TEACHERS}

\section{TORN OUT OF THE COMFORT ZONE}

Middle schools appeared in the Polish educational system following the reform of 1999 that established three types of schools: 6-year primary schools, 3-year middle schools, and 3-year secondary schools. A significant feature of that reform, 
as pointed out by Marta Zahorska (2009), was its comprehensiveness. Changes in the school system were introduced concurrently with new management principles, a new manner of financing educational institutions, new curricula along with a new examining system. Additionally, changes involved teachers' promotion procedures, and new principles of school functioning were formulated.

The emergence of a new type of schools inspired the examined teachers who worked at that time to actively co-create the changes and build personal brands of their schools. The undertaken activities and their consistent implementation for eighteen years resulted in high positions in local and national school ratings achieved by all examined middle schools. In practice, this meant that after a few years of consistently realized new educational conception, originally designed and constantly perfected, the analyzed middle schools became schools of the so-called first choice. Ever higher ratings and strong prestigious positions of the schools in the local environments triggered the feedback effect. The high rating of these middle schools made them of interest to pupils who had significant educational achievements, were motivated, and came from families that supported children's educational ambitions. Pupils' educational successes, including the enrolment of the graduates to the best secondary schools, ensured retaining a high reputation and rating for these middle schools:

it works like this when you do a good exam result then parents look at it and with a good exam result you get better pupils and better pupils do a still better result and you again get better pupils and this is such a spiral (N1:5). ${ }^{3}$

A turning point for middle schools was a decision made by central authorities to dissolve them (close them down). Despite earlier announcements, already during the parliamentary election campaign, the examined teachers found it difficult to believe, understand and accept the fact that one arbitrarily made decision might destroy the many years of successful work and achievements of their schools:

I till the end (3) till the last day believed that someone (.) maybe the President will stop this, that maybe they will turn us into some experimental schools, but not close us down just with one move (N4:1).

Teachers' disbelief was grounded since the arguments employed to justify the necessity to dissolve middle schools were not substantive. These arguments were supported with propaganda ideas, two of which resonated well with the public.

3 The symbols accompanying the excerpts from interviews are identification codes used in the study eg. $\mathrm{N} 1,2, \ldots 4$ school numbers , $1,2, \ldots 5$ narrators number. 
The first one demonized puberty as a developmental stage that generates exceptional behavioural issues; the second one questioned the effectiveness/quality of education in middle schools. Both types of arguments enforced a vision that middle schools teaching staff was completely helpless:

the worst thing was that nobody cared about our opinion (!), it just seemed unbelievable that we may be closed down without being asked about our opinion and only again and again how hopeless we are (N2:5).

Despite strong negative emotions and the sense of losing autonomy and agency, teachers, by the driving force of reformatory activities, were 'drawn into' the mechanism of the transition process. In the first stage, the basic problem that the examined teachers had to face was the decision concerning the future of their school. This stage occurred in each of the examined middle schools in several interlinked sequences, with the interests of local politics - self-governmental and educational - creating the context.

The driving force behind the 'battle for a new school' may be termed 'teleological pragmatics'. In the examined schools, teachers, leaning towards transforming the middle school into a general education secondary school, hoped not only to keep their jobs but also to preserve their individual and collective achievements. Apart from axiological motivations, there existed also pragmatic grounds. Demographic determinants were of key importance for all schools. Middle schools, in which the study was conducted, are located near city centres that serve mainly service and administrative as well as tourist and entertaining functions in large cities. This is a serious obstacle to ensure enrolment for schools, especially for primary schools. Driving children to school from remote residential districts is a critical logistical problem that not many parents wish to undertake. Hence the transformation of the middle school into a primary school seemed doomed to fail. Another problem that the schools had to face when considering alternative profile options were architectural barriers. The historical character of school buildings and their status as monuments of architecture were decisive when considering the application for a historic preservation officer's consent to be able to make alterations and establish a school of, for instance, a technical profile. Additionally, an important motivation behind choosing the type of school that the middle school was supposed to be transformed into were the expectations of teachers themselves, who preferred to work with older pupils, describing such work as more stimulating and giving them more professional satisfaction.

An important driving force at this early stage of transition were tensions between teachers of middle schools to be dissolved and school governing authori- 
ties and pedagogic supervisory bodies. The fierceness of the dispute in this respect was correlative to the conflict of different and opposing interests, encompassing both particular and individual interests, and ideological ones.

Schools, whose transitions were examined during the study, are very attractively located. Allotting the buildings for other purposes than educational ones might bring tangible benefits for municipal budgets. Hence the idea to transform middle schools into secondary schools was opposed by local authorities that postulated either the closing down of the schools or transforming them into primary schools or branches of primary schools that would be gradually moved to other locations. A similar dispute, often quite dramatic, was generated by meetings of teachers and pedagogic supervisory bodies that were also inimical to the idea of establishing new secondary schools in the cities:

the plan in relation to us was that we were to be reduced to a branch of a primary school since such was the premise and this was only because the main role was played by jaundice littleness and incompetence. When you analyze such transformations you should take into consideration not only the quality of the school that got transformed into a secondary school or another type but also deals in the city right?? [...] maybe it wasn't like that everywhere, but here it resonated most vividly (N2:1).

In this atmosphere of authorities' reluctance and pressures to implement a different conception of the school transformation, teachers, supported only by a small group of parents, attempted to neutralize the arguments for closing the school down as forced by the authorities. The major concern, and concurrently the key argument ensuring the survival of the school in the new formula, were the results of the enrolment to the newly-established secondary school.

This sequence, in which the uncertainty of administrative decisions combined with everyday educational challenges and slightly forgotten endeavours to recruit pupils no longer to a prestigious middle school but to a general education secondary school of an ungrounded position, required from teachers and other school employees determination and a huge amount of energy and time:

but what caused this yeah: the fact that apparently we are first to transform into a branch, then something was [decided] and finally that we are a secondary school but children didn't know at all that we are a secondary school and all this despite an advertising campaign despite an open day [organized] twice and advertisements everywhere wherever only possible in buses, trams [...] it wasn't known nobody knew about our existence (N2:8).

and the city does nothing yeah::: I think to help inform that in these great middle schools there will be secondary schools and they will soon be great secondary schools (N2:9). 
The consent to transform middle schools into secondary schools, obtained after many 'skirmishes' and burdensome and exhausting twists of events, triggered the beginning of a new sequence that occurred in the context of different interests of particular groups of employees and the absence of support for the transition process on the part of central and local authorities:

you know they still keep their fingers crossed for us to fail (N3:11).

When we move to a new flat, get promoted in work, a child is born to us, we change our job, the transfer often occurs very quickly because it is of a situational nature. An internal psychological change (from a subordinate worker to a chief, from a childless person to a parent, from a middle school teacher to a secondary school teacher) is much slower. Even positive changes, as observed by W. Bridges (2008), are associated with giving up something that thus far was known and almost obvious. Hence the transition begins with the ending, i.e., experiencing a sense of loss and resignation.

\section{WHAT IS LEFT FOR US...}

When the process of middle schools dissolution was decided, teachers entered into a new sequence of the transition. The intensity of the pace of this stage was correlative in each school to a different configuration of several overlapping driving forces: the reform itself, its program and rhythm, tensions that emerged at the intersection of conflicting interests of individuals and groups involved in the change at the intra-school level, the sense of a lack of agency, and disapproval for the manner in which the reform was implemented.

The entering into the phase of transition understood as a process of a psychological relocation of individuals, during which one's identity is (re)constructed, begins, as observed by W. Bridges, with balancing personal losses incurred by the change:

we come to work tired sleepy this means that we are less patient and it’s easier to @ get us flustered@ no point in kidding ourselves I of course don't want to generalize maybe I'm the only one butI'm afraid@@@ I'm not @ this affects many things 'cause this affects both relations between us and relations at home and relations with pupils (3) shortly speaking (N5:2 incomprehensible text). and I personally am very tired also physically I'm very tired (N5:4). 
The cost paid by the teachers, mostly in the professional dimension, is huge, and as is evident from the comparative analysis, encompasses many areas of their professional activities. Losses that are most strongly sensed relate to the lowering of one's self-esteem, the lowering of the rank and position of the school, the change in the patterns of fulfilling the basic professional activity (teaching process).

A significant loss, perceived very personally by the teachers, was the lowering of the school prestige and its established position. Following many years of building their reputation, prestigious middle schools, transformed into newly established secondary schools, had to fight for pupils (school of subsequent choices) and adapt their educational offer and working standards to a new type of pupil/parent and their needs:

we were simply not used to it a pupil who is happy to get a mere pass [a grade allowing to pass - H.K.] get credit and forget about it this is I believe a typical pupil in secondary schools yeah: onlywe are spoiled after the middle school [@@ laughter of several people@@ overlapping voices, incomprehensible fragment] and I'm not saying I'm happy about it I think we have to get used to it but I believe it is like this (N1:8).

Innovative didactic ideas, styles of working with pupils, teaching methods, ways of organizing school work and cooperating with the external environment (all tested and effective since they had been modified and perfected for years) lost their validity overnight. Along with the enrolment of pupils to the secondary school (while working simultaneously in middle school classes), new core curricula and examining standards appeared and forced a redefinition of the basic professional activity and its implementation in all its dimensions:

I feel you know like after graduating from university (.) I have to prepare almost like a trainee teacher back then outlines lesson plans all that to polish up I'm aware of matura [school leaving final exam] so I look for matura tasks for each chapter to show them what these look like on the matura exam what this range of material looks like so I prepare myself (.) moreover I attend such meetings at the campus we have once a month meetings for teachers and::: there we prepare ourselves for the new matura also the one after a four-year secondary school (N1:4).

Exhaustion caused by fighting for the survival of the school, intensive activities focused on the promotion of the new school and successful enrolment, teaching in classes following different core curricula, and working with pupils characterized by a much lower achievement motivation, the absence of any support provided by education supervisory bodies and self-government authorities made the psychological relocation an exceptionally difficult experience, both personally and pro- 
fessionally, for the examined teachers. The answer to the question: "What's next?", became the turning point in professional trajectories for all examined teachers.

The comparative analysis between specific cases allowed for identifying three patterns of teachers' individual transitions in the first stage of the process.

Teachers who spent a large part of their professional life in the middle school, building it and its prestige from scratch, having acquired retirement rights, decided to leave their job, thus leaving the transition process:

I retire as of the next year. I don't want to stay, I worked very hard when the middle school was being established and I'm happy about it because these were great years of my work but I don't want to start all this from the beginning (N3:9).

Teachers for whom working under the conditions of transition became uncomfortable, both economically and professionally, also decided to leave the school at the end of the school year and to search for work in other sectors of the economy:

I will work only until holidays I'm fed up I've got employed in a corpo (N3:6).

The third path, followed by the greatest number of teachers in the studied group, was represented by those teachers who decided to stay in the teaching profession and the transformed school. This group is not homogeneous. Three types of teachers may be identified within it, representing different approaches to their future.

Transitional optimists are those teachers who, despite being convinced that their long-years of professional achievements are being ruined and irrespective of their disappointment with the outcomes of the reform, perceive the change as a challenge and an opportunity to do something new and as a new professional experience:

since we managed once then we will built a great school now as after all we know how to do it (N1:2).

Transitional realists are more reserved as to the possibility of repeating the success of their middle school, afraid of becoming involved again, and worried about personal and collective costs of the change:

the problem begins when despite our efforts we head into the vacuum right and:: we try to prepare additional material a million of different extra exercises we spend over one subject as much time as is allocated according to the curriculum and still you don't get what you would like and this is a bit frustrating (N2:8). 
Pessimists do not believe that the success of the middle school can be repeated, are disappointed and focused on adapting to the new reality, often quite superficially. Their presence at school is motivated by the lack of employment alternative, being accustomed to school, fear of the change, and approaching retirement:

I have my own way to deal with this I try to do what I have to do and not think too much because we don't have any influence on anything that's what we've found out right? (N5:6)

Overcoming two obstacles will be of key importance for the organization as regards the course of this sequence and moving to the further stages of the process. The first one concerns the difficulty in managing transition that is caused by the change in the teaching staff employment structure. The outflow of experienced and involved teachers who co-created the organizational culture in the middle school, and replacing them with employees who do not share the same experience, may weaken the collective effort to achieve the best educational outcomes and the results of the first matura exam in the new type of school. The appearance of new employees requires the newcomers to get integrated with the already existing community and their gradual inclusion into the school practice. This generates tensions resulting from the questioning of the old order by the newcomers, "hence questioning the meanings that need to be renegotiated in the community" (Rozkosz, 2017, p. 108). For new teachers, irrespective of their years of service, the sense of loss and ending experienced by the employees of the former middle school may be incomprehensible, just as the aims of the transition process itself - the preservation of the school achievements. Joining the community of practicing teachers by the newcomers (Wenger, 1998) and the peripheral position of transitional pessimists may block the adaptation of the organization to the new environment.

The process of moving to the second stage of the transition (neutral zone) requires abandoning old, tested ways of thinking and acting that used to ensure success of the school but in new circumstances become a burden which hinders changes:

The level of pupils that we get has changed substantially (3) we raised laureates, finalists yeah but unfortunately most of them have chosen other secondary schools more reputable whereas us especially in the first enrolment these were children of a definitely lower intellectual potential and with psychological problems, behavioural issues that we never had before (N1:3). and we are overwhelmed by our own ambitions (N1:6). 
The application of tested educational and organizational practices in the new environment of the secondary school as a strategy of change may not bring the expected outcomes:

we talk in the staff room practically every day and we have an impression that we all try very hard we prepare for each lesson we give the maximum of ourselves and we meet with what - with a wall it didn’t used to be like that (N1:11).

Transitions are dynamic processes during which people receive contradictory messages, are overloaded, and sense a reduced efficiency of their own actions. They undertake cost-inducing individual and collective activities to manage the new reality. Unfortunately, the transition between subsequent phases does not occur automatically, always at the same pace and does not follow the same course patterns. As regards its situational dimension, its beginning and closure may be declared. In the psychological dimension, the transition may end in failure, bringing disillusionment to the people involved.

\section{CONCLUSIONS}

The histories of personal transitions provided by the studied teachers consist of many pictures that, as in a kaleidoscope, although built from the same elements, assume a different shape issuing from the slightest movement. Decoding the meanings of these complex multidimensional processes, changing with time, is a complicated, analytical work involving the untangling of overlapping sequences of events emerging via interactions among many ingredients that affect each other, hence modifying not only their own meanings, but also the meaning of the entire process.

The conducted processual analysis of the transition of middle school teachers allows one to understand and describe the dramatic nature of the 'battle for a new school' fought by the teachers of the studied middle schools. The results of the comparative analysis also allow one to question two axioms relating to teachers' work characteristic for normative teacher training.

The first one is related to the conviction that the quality of work done by a single teacher is decisive with respect to the quality of work at the school. The analysis of transitions experienced by middle school teachers in the temporal dimension proves that school is a complex system whose components do not constitute a simple sum, but are interrelated and affect each other. 
The second one stems from reducing the process of change in the education system to its situational dimension, consequently transferring the psychological costs of the reform implementation to the school and those teachers employed therein. Considering the issue from the perspective of the systemic change, one can agree with the thesis that the reformed schools 'dealt with the change'. However, considering the issue from the perspective of a psychological process, it would be worthwhile to ponder whether this is not indeed a Pyrrhic victory.

\section{References}

Barbour, R. (2011). Badania fokusowe. Warszawa: PWN.

Beadle, H. (2017). A Procession of Change: Argument for the Use of the Processual Approach in Examining School Based Organisational Change. Teacher Education Advancement Network Journal, 9(1), pp. 14-21.

Bidart, C., Longo, M.E., \& Mendez, A. (2013). Time and Process: An Operational Framework for Processual Analysis. European Sociological Review, 29(4), pp. 743-751. DOI: 10.1093/esr/jcs053.

Bridges, W. (2008). Zarzqdzanie zmianami. Jak maksymalnie skorzystać na procesach przejściowych. Kraków: Wyd. Naukowe UJ.

Brotherson, S.E., \& Moen, D.A. (2011). Establishing a Home: A Study of Practical Dimensions in the Transition to Marriage. Family Science Review, 16(2), pp. 59-75.

Charmaz, K. (2009). Teoria ugruntowana. Praktyczny przewodnik po analizie jakościowej. Warszawa: Wyd. Naukowe PWN.

Drabik-Podgórna, V. (2010). Tranzycja jako nowa kategoria biograficzna we współczesnym poradnictwie zawodowym. Edukacja Dorosłych, 1, pp. 91-104.

Ecclestone, K. (2009). Lost and Found in Transition: The Implications of 'Identity', 'Agency' and 'Structure' for Educational Goals and Practices. In: J. Field, J. Gallacher, \& R. Ingram (Eds.), Researching Transitions in Lifelong Learning. London-New York: Routledge Taylor \& Francis Group. Retrieved from: https://pdfs.semanticscholar.org/ 31db/123c152d22f4c6ec4130f378a73f00fa73a5.pdf?_ga=2.108829826.1872879869.1591 709356-849102905.1585341051 (accessed: 14.02.2018).

Erikson, E.H. (2004). Tożsamość a cykl życia. Poznań: Wyd. Zysk i S-ka.

Flick, U. (2010). Projektowanie badania jakościowego. Warszawa: Wyd. Naukowe PWN.

Fogel, A. (2006). Dynamic Systems Research on Interindividual Communication: The Transformation of Meaning-Making. The Journal of Developmental Processes, 1(1), pp. 7-30.

Kędzierska, H. (2019). Nauczyciele gimnazjum - w poszukiwaniu nowej, profesjonalnej tożsamości. Przegląd Pedagogiczny, 2, pp. 66-78.

Manstead, A.S.R. (2018). The Psychology of Social Class: How Socioeconomic Status Impacts Thought, Feelings, and Behaviour. British Journal of Social Psychology, 57(2), pp. 267291. DOI: 10.1111/bjso.12251.

McLeod, Ch., Heriot, S., \& Hunt, C. (2008). Changing Places: Resilience in Children Who Move. Australian Journal of Education, 52(2), pp. 168-182. DOI: 10.1177/00049441080 5200205. 
Mizerek, H. (2017). Studium przypadku w badaniach nad edukacją. Istota i paleta zastosowań. Przegląd Pedagogiczny, 1, pp. 9-22.

Moffatt, S., \& Heaven, B. (2017). 'Planning for Uncertainty': Narratives on Retirement Transition Experiences. Ageing \& Society, 37(5), pp. 879-898. DOI: 10.1017/S0144686X15001476.

Müller, W., \& Gangl, M. (2003). The Transition from School to Work: A European Perspective. In: W. Müller, \& M. Gangl (Eds.), Transitions from Education to Work in Europe (pp. 1-19). Oxford: Oxford University Press.

Pettigrew, A.M. (1997). What is a Processual Analysis? Scandinavian Journal of Management, 13(4), pp. 337-348. DOI: 10.1016/S0956-5221(97)00020-1.

Piróg, D. (2013). Wybrane determinanty tranzycji absolwentów studiów wyższych na rynek pracy. Dylematy współczesnego rynku pracy. Studia Ekonomiczne. Zeszyty Naukowe Wydziałowe UE w Katowicach, 160, pp. 131-138.

Rozkosz, E. (2017). Teoria Etienne’a Wengera w badaniach usytuowanego uczenia się kompetencji informacyjnych. Forum Oświatowe, 29(1), pp. 97-128.

Rzechowska, E. (2011). Podejście procesualne: warianty badań nad procesami w mikroi makroskali. Roczniki Psychologiczne, 14(1), pp. 127-157.

Schlossberg, N.K. (1981). A Model for Analyzing Human Adaptation to Transition. Counselling Psychologist, 9(2), pp. 2-18. DOI: 10.1177/001100008100900202.

Simons, H. (2009). Case Study Research in Practice. London: Sage.

Sullivan, S.E., \& Al Ariss, A. (2019). Making Sense of Different Perspectives on Career Transitions: A Review and Agenda for Future Research. Human Resource Management Review. DOI: 10.1016/j.hrmr.2019.100727.

Taubman-Ben-Ari, O., Shlomo, S., Sivan, E., \& Dolizki, M. (2009). The Transition to Motherhood - a Time for Growth. Journal of Social and Clinical Psychology, 28(8), pp. 943-970. DOI:10.1521/jscp.2009.28.8.943.

Wenger, E. (1998). Communities of Practice: Learning, Meaning, and Identity. New York, NY: Cambridge University Press.

Zahorska, M. (2009). Sukcesy i porażki reformy edukacji. Przegląd Socjologiczny, 58(3), pp. 119-142.

Zittoun, T. (2008). Learning through Transitions: The Role of Institutions. European Journal of Psychology of Education, 23(2), pp. 165-181. DOI: 10.1007/BF03172743.

Zittoun, T. (2009). Dynamics of Life-Course Transitions: A Methodological Reflection. In: J. Valsiner, P. Molenaar, M. Lyra, \& N. Chaudhary (Eds.), Dynamic Process Methodology in the Social and Developmental Sciences (pp. 405-430). New York: Springer.

Zmiany w systemie oświaty. Raport NIK. (2009). Retrieved from: https://www.nik.gov.pl/kontrole/P/18/027/. 